\title{
EDITORIAL
}

\section{Fenfluramine: riddle or Rosetta stone?}

\author{
E.K. Weir, M. Obreztchikova and Z. Hong
}

a diopathic pulmonary arterial hypertension (IPAH) used to be called primary pulmonary hypertension. Both terms indicate that we do not yet fully understand the aetiology of the disease. A clue to the underlying mechanisms lies in the observation that the appetite-suppressant drugs aminorex [1, 2] and fenfluramine [3] were both associated with a marked increase in the incidence of pulmonary arterial hypertension (PAH) while they were available in Europe. Although they are no longer prescribed, it is important to study them to gain an understanding of IPAH and to ensure that new drugs do not have the potential to cause pulmonary hypertension. In general, there is no clinical or pathological way to distinguish $\mathrm{PAH}$ associated with these anorectic agents from IPAH independent of them. This point is clearly made in a study by SouzA et al. [4] in the present issue of the European Respiratory Journal. SOUZA et al. [4] describe the follow-up of 109 patients diagnosed with $\mathrm{PAH}$ in association with exposure to fenfluramine between 1986 and 2004. In virtually every respect, the presentation and clinical course of these patients was the same as that of patients with IPAH who were diagnosed over the same period. Interestingly, $18 \%$ of the fenfluramine PAH patients had a bone morphogenic protein receptor 2 (BMPR2) gene mutation, a very similar incidence to that observed in sporadic IPAH [5]. This suggests the likelihood of underlying genetic susceptibility that renders both groups vulnerable, perhaps to a similar second hit.

\section{FENFLURAMINE-INDUCED VALVE DISEASE}

There is one marked difference in the spectrum of disease caused by fenfluramine and that seen in IPAH. Although fenfluramine was recognised to cause PAH it was actually withdrawn from the market in 1997 because of an associated cardiac valvulopathy [6]. The valvulopathy does not occur in IPAH but resembles that seen in clinical carcinoid heart disease, where high levels of 5-hydroxytryptamine (5-HT) are primarily responsible. Indeed, chronic systemic administration of 5-HT in rats has been demonstrated to cause valvulopathy and myofibroblast proliferation [7]. The fenfluramine-related valvulopathy is thought to be caused by stimulation of the

Dept of Medicine, Veterans Affairs Medical Centre, and University of Minnesota, Minneapolis, MN, USA.

SUPPORT STATEMENT: E.K. Weir is supported by a National Heart, Lung and Blood Institute grant R01 HL-65322.

STATEMENT OF INTEREST: A statement of interest for $Z$. Hong can be found at www.erj. ersjournals.com/misc/statements.shtml

CORRESPONDENCE: E.K. Weir, Veterans Affairs Medical Center 111C, 1 Veterans Drive, Minneapolis, MN 55417, USA. Fax: 1 6127275668. E-mail: weirx002@umn.edu
5-HT2B receptor by the metabolite norfenfluramine [8]. 5-HT acts on cells not only by binding to receptors on the cell surface but also by being taken up into the cell through the 5-HT transporter (5-HTT). Genetically induced deficiency of the 5HTT in mice also leads to valvulopathy and fibrosis [9]. Fenfluramine inhibits the 5-HTT, in addition to stimulating the 5-HT2B receptor, so both activities may play a role.

In general, patients with PAH associated with fenfluramine did not develop valvulopathy. Conversely, patients who had valvulopathy associated with fenfluramine usually had pulmonary artery pressures compatible with the valve defect, rather than severe PAH. The question then arises, why did some patients who took fenfluramine develop valvulopathy, some develop PAH and most have no clinical sequelae?

\section{ELEVATION OF PLASMA 5-HT LEVELS}

Plasma 5-HT is increased in rats treated with fenfluramine, or its D-isomer dexfenfluramine [10-12]. This may occur because dexfenfluramine blocks uptake of 5-HT by the 5-HTT but if that were the only mechanism of the associated PAH in patients, then the serotonin reuptake inhibitors (SSRIs), such as fluoxetine, which are widely used, would cause PAH. They do not. In fact, the SSRIs appear to have a beneficial effect in animal models of pulmonary hypertension [13] and possibly in patients [14]. Most of the 5-HT in the blood is in the platelets, but the increased plasma level caused by dexfenfluramine is not the result of 5-HT release from the platelets, as the concentration of dexfenfluramine required for release is far above that achieved clinically [15]. In IPAH, 5-HT levels are increased, even after lung transplantation [16]. This observation, made in 1995, indicates that 5-HT plays an aetiological role in IPAH or is linked to the aetiological mechanism. Although 5-HT is involved in the mechanism of IPAH and in the carcinoid valvulopathy, patients with IPAH do not have valvulopathy. Conversely, any pulmonary hypertension in carcinoid valvulopathy is in keeping with the severity of the valve disease, rather than suggesting concomitant IPAH. It is hard to explain these differences on the basis of the duration of exposure or the level of plasma serotonin. It seems likely that the difference lies in the genetic substrate of IPAH, including differences in the function and/or expression of BMPR2, 5HTT, 5-HT receptors and possibly potassium $\left(\mathrm{K}^{+}\right)$channels.

\section{5-HT AND 5-HTT IN ANIMAL MODELS}

The mechanism of chronic hypoxic pulmonary hypertension clearly involves 5-HT. Genetic deletion of the enzyme responsible for the synthesis of 5-HT, tryptophan hydroxylase, reduces pulmonary hypertension and pulmonary vascular remodelling caused by chronic hypoxia in mice $[17,18]$. The tryptophan hydroxylase inhibitor, p-chlorophenyladenine, has 
similar effects [18]. Comparable evidence demonstrates the role of the 5-HTT. Hypoxia increases expression of 5-HTT in pulmonary artery smooth muscle (PASMC) [19]. Mice that are genetically deficient for 5-HTT develop less pulmonary hypertension and pulmonary vascular remodelling in chronic hypoxia than wild-type mice [20]. Conversely, overexpression of the gene for 5-HTT in mice increases right heart pressures and vascular remodelling in response to chronic hypoxia [21] The observation that the ability of 5-HT to cause proliferation of PASMCs is blocked by 5-HTT uptake inhibitors, such as fluoxetine, also illustrates the potential importance of the 5-HTT [22]. Assessing the role of the 5-HTT in the mechanisms underlying $\mathrm{PAH}$ is particularly relevant in the case of fenfluramine. Both the anorectic drugs that have been associated with outbreaks of $\mathrm{PAH}$, aminorex and fenfluramine, are avidly taken up by the 5-HTT compared with other drugs [23]. All the observations cited suggest that in chronic hypoxia the uptake of 5-HT by the 5-HTT will lead to PASMC proliferation. Similarly, the uptake of fenfluramine by the 5HTT, like 5-HT, leads to smooth muscle proliferation and pulmonary vascular remodelling [24].

\section{5-HT IN IPAH}

5-HTT expression is increased in the PASMC of IPAH patients [25]. These smooth muscle cells proliferate more rapidly than controls when stimulated with 5-HT. A genetic basis for the increased expression of the 5-HTT exists in the finding that the homozygous form of the L allele of the 5-HTT gene promoter is more common in patients with severe IPAH than in controls [25]. Human pulmonary artery endothelial cells (PAECs) synthesise 5-HT [26] and, when stimulated, PAECs from IPAH patients generate more 5-HT than PAECs from control subjects. The tryptophan hydroxylase responsible for this 5-HT synthesis can be demonstrated on immunostaining to be confined to the intima. These observations indicate that while most of the 5-HT in the body may be produced by the enterochromaffin cells of the small bowel, some is formed in the lung vessels.

Immunostaining of lungs from patients with IPAH, secondary $\mathrm{PAH}$ and pulmonary veno-occlusive disease shows the presence of 5-HT receptors (5-HT1B, 5-HT2A, 5-HT2B), as well as 5-HTT in the vessels [27]. However, the proliferation caused by 5 -HT in the cultured PASMCs from these patients appears to be related primarily to the activity of the 5-HTT, as it can be totally prevented by 5-HTT blockers but not by 5-HT receptor antagonists. In trying to decide whether the 5-HTT or the 5-HT receptors play a more important role in IPAH, this experiment has to be reconciled with the observation that genetic deficiency of 5-HT2B in mice reduces their pulmonary hypertension and pulmonary vascular remodelling in response to chronic hypoxia [28]. Fortunately, it has been suggested that both 5-HTT activity and 5-HT receptor stimulation are necessary for the full mitogenic activity of 5-HT on PASMCs [29]. Proliferation is induced by 5-HT which is taken up by the 5-HTT and in turn activates extracellular signal-regulated kinase (ERK)1/ERK2, but translocation of ERK1/ERK2 to the nucleus requires Rho kinase activity that is triggered by 5-HT interaction with the 5-HT1B/1D receptors. Earlier work makes it likely that dexfenfluramine also uses both 5-HTT and 5-HT receptor pathways [25].

\section{$\mathrm{K}^{+}$CHANNELS AND 5-HT}

There is a parallel mechanism to the 5-HT pathway that has to be put in perspective and it relates to $\mathrm{K}^{+}$channels. The anorectic agents fenfluramine and aminorex both inhibit $\mathrm{K}^{+}$ channels in PASMCs, causing membrane depolarisation and calcium entry through L-type calcium channels [30]. The metabolite nordexfenfluramine stimulates calcium release from the sarcoplasmic reticulum and calcium entry through store-operated channels [31]. Decreased $\mathrm{K}^{+}$channel expression or function in PASMCs is also reported in chronic hypoxic pulmonary hypertension [32], spontaneous pulmonary hypertension in the fawn-hooded rat [33] and in IPAH patients [34]. $\mathrm{K}^{+}$channel inhibition leads to decreased apoptosis through a rise in cytosolic $\mathrm{K}^{+}$and to increased proliferation through a rise in cytosolic $\mathrm{Ca}^{++}$[35]. There are several interactions between the $\mathrm{K}^{+}$channels and 5-HT. Dexfenfluramine increases 5-HT release from the enterochromaffin cells of the small intestine [36] and this effect is mimicked by the classical $K_{v}$ channel inhibitor, 4-aminopyridine. This may help to explain the increased plasma 5-HT levels in fenfluramine-induced PAH. If the $\mathrm{K}^{+}$channel abnormality seen in IPAH in PASMCs is more widely distributed and occurs in enterochromaffin cells, it might also explain the increased plasma 5-HT seen there. The fawn-hooded rat, which develops spontaneous pulmonary hypertension, has both increased plasma 5-HT and decreased $\mathrm{K}^{+}$channel activity in the PASMCs [33]. Whether one abnormality precedes the other is not clear. However, the final clues to the riddle are as follows. First, that overexpression of the 5-HTT results in decreased smooth muscle levels of mRNA for $K_{v} 1.5$ and $K_{v} 2.1$ channels [37], and secondly, that the inhibition of $\mathrm{K}_{\mathrm{v}} 1.5$ mRNA can be achieved by incubating PASMCs with 5-HT. The latter action can be inhibited by pretreatment with the 5-HTT blocker fluoxetine. Thus, on the one hand, fenfluramine and $\mathrm{K}^{+}$channel blockers can increase 5-HT release, while on the other, 5-HT can inhibit $\mathrm{K}^{+}$channel mRNA [37] and activity [38]. Consistent with this information is the observation that $\mathrm{BMP} 2$, the ligand for the BMPR2 receptor, which tends to downregulate 5-HT signalling, increases both $\mathrm{K}^{+}$channel function and expression in PASMCs [39].

The report by SouzA et al. [4] reminds us of the severe, life-long consequences that can be triggered by the relatively short use of some anorectic agents. In the case of pulmonary arterial hypertension associated with fenfluramine, the pathophysiological features that it shares with idiopathic pulmonary arterial hypertension are increased plasma 5-hydroxytryptamine, abnormal function of the 5-hydroxytrypytamine transporter (possible involvement of 5-hydroxytrypytamine receptors) and a decrease in $\mathrm{K}^{+}$channel function/expression. New drugs should be screened for these characteristics. We are beginning to understand the hieroglyphics on our Rosetta stone.

\section{REFERENCES}

1 Gurtner H. Pulmonary hypertension, "plexogenic pulmonary arteriopathy" and the appetite depressant drug aminorex: post or propter. Bull Eur Physiopath Res 1979; 15: 897-923.

2 Greiser E. Epidemiologische untersuchungen zum zusammenhang zwischen appetitzueglere innahme und primaer vasculaer pulmonaler hypertonie. [Epidemiologic studies 
on the relation between use of appetite depressants and primary vascular pulmonary hypertension.] Internist 1973; 14: 437-442.

3 Abenhaim L, Moride Y, Brenot F, et al. Appetite-suppressant drugs and the risk of primary pulmonary hypertension. N Engl J Med 1996; 335: 609-616.

4 Souza R, Humbert M, Sztrymf B, et al. Pulmonary arterial hypertension associated with fenfluramine exposure: report of 109 cases. Eur Respir J 2008; 31: 343-348.

5 Thompson J, Machado R, Pauciulo M, et al. Sporadic primary pulmonary hypertension is associated with germline mutations of the gene encoding BMPR-II, a receptor member of the TGF- $\beta$ family. J Med Genet 2003; 37: 741-745.

6 From the Centers for Disease Control and Prevention. Cardiac valuvulopathy associated with exposure to fenfluramine or dexfenfluramine: US Department of Health and Human Services interim public health recommendations, November 1997. JAMA 1997; 278: 1729-1731.

7 Gustafsson B, Tømmerås K, Nordrum I, et al. Long-term serotonin administration induces heart valve disease in rats. Circulation 2005; 111: 1517-1522.

8 Fitzgerald L, Burn T, Brown B, et al. Possible role of valvular serotonin 5-HT(2B) receptors in the cardiopathy associated with fenfluramine. Mol Pharmacol 2000; 57: 75-81.

9 Mekontso-Dessap A, Brouri F, Pascal O, et al. Deficiency of the 5-hydroxytryptamine transporter gene leads to cardiac fibrosis and valvulopathy in mice. Circulation 2006; 113: 81-89.

10 Celada P, Martín F, Artigas F. Effects of chronic treatment with dexfenfluramine on serotonin in rat blood, brain and lung tissue. Life Sci 1994; 55: 1237-1243.

11 Eddahibi S, Raffestin B, Launay J, Sitbon M, Adnot S. Effect of dexfenfluarmine treatment in rats exposed to acute and chronic hypoxia. Am J Respir Crit Care Med 1998; 157: 1111-1119.

12 Zolkowska D, Rothman R, Baumann M. Amphetamine analogs increase plasma serotonin: implications for cardiac and pulmonary disease. J Pharmacol Exp Ther 2006; 318: 604-610.

13 Guignabert C, Raffestin B, Benferhat R, et al. Serotonin transporter inhibition prevents and reverses monocrotalineinduced pulmonary hypertension in rats. Circulation 2005; 111: 2812-2819.

14 Kawut S, Horn E, Berekashvili K, et al. Selective serotonin reuptake inhibitor use and outcomes in pulmonary arterial hypertension. Pulm Pharmacol Ther 2006; 19: 370-374.

15 Johnson G, Leis L, Dunlop P, Weir E. The effect of the anorectic agent, d-fenfluramine, and its primary metabolite, d-norfenfluramine, on intact human platelet serotonin uptake and efflux. J Thromb Haemost 2003; 1: 2663-2668.

16 Herve P, Launay J, Scrobohaci M, et al. Increased plasma serotonin in primary pulmonary hypertension. Am J Med 1995; 99: 249-254.

17 Morecroft I, Dempsie Y, Bader M, et al. Effect of tryptophan hydroxylase 1 deficiency on the development of hypoxiainduced pulmonary hypertension. Hypertension 2007; 49: 232-236.

18 Izikki M, Hanoun N, Marcos E, et al. Tryptophan hydroxylase 1 knockout and tryptophan hydroxylase 2 polymorphism: effects on hypoxic pulmonary hypertension in mice. Am J Physiol 2007; 293: L1045-L1052.
19 Eddahibi S, Fabre V, Boni C, et al. Induction of serotonin transporter by hypoxia in pulmonary vascular smooth muscle cells. Relationship with the mitogenic action of serotonin. Circ Res 1999; 84: 329-336.

20 Eddahibi S, Hanoun N, Lanfumey L, et al. Attenuated hypoxic pulmonary hypertension in mice lacking the 5hydroxytryptamine transporter gene. J Clin Invest 2000; 105: 1555-1562.

21 MacLean M, Deuchar G, Hicks M, et al. Over-expression of the 5-hydroxytryptamine transporter gene: effect on pulmonary haemodynamics and hypoxia-induced pulmonary hypertension. Circulation 2004; 109: 2150-2155.

22 Lee S, Weng W, Lanzillo J, Fanburg B. Serotonin produces both hyperplasia and hypertrophy of bovine pulmonary artery smooth muscle cells in culture. Am J Physiol 1994; 266: L46-L52.

23 Rothman R, Ayestas M, Dersch C, Baumann M. Aminorex, fenfluramine and chlorphentermine are serotonin transporter substrates. Implications for primary pulmonary hypertension. Circulation 1999; 100: 869-875.

24 Lee S, Wang W, Fanburg B. Dexfenfluramine as a mitogen signals through the formation of superoxide anion. FASEB J 2001; 15: 1324-1325.

25 Eddahibi S, Humbert M, Fadel E, et al. Serotonin transporter overexpression is responsible for pulmonary artery smooth muscle hyperplasia in primary pulmonary hypertension. J Clin Invest 2001; 108: 1141-1150.

26 Eddahibi S, Guignaber C, Barlier-Mur A, et al. Cross talk between endothelial and smooth muscle cells in pulmonary hypertension: critical role for serotonin-induced smooth muscle hyperplasia. Circulation 2006; 113: 1857-1864.

27 Marcos E, Fadel E, Sanchez O, et al. Serotonin transporter and receptors in various forms of human pulmonary hypertension. Chest 2005; 128: Suppl. 6, 552S-553S.

28 Launay J, Hervé P, Peoc'h K, et al. Function of the serotonin 5-hydroxytryptamine $2 \mathrm{~B}$ receptor in pulmonary hypertension. Nat Med 2002; 8: 1129-1135.

29 Liu Y, Suzuki Y, Day R, Fanburg B. Rho kinase-induced nuclear translocation of ERK1/ERK2 in smooth muscle cell mitogenesis caused by serotonin. Circ Res 2004; 95: 579-586.

30 Weir E, Reeve H, Huang J, et al. Anorexic agents aminorex, fenfluramine, and dexfenfluramine inhibit potassium current in rat pulmonary vascular smooth muscle and cause pulmonary vasoconstriction. Circulation 1996; 94: 2216-2220.

31 Hong Z, Olschewski A, Reeve H, Nelson D, Hong F, Weir E. Nordexfenfluramine causes more severe pulmonary vasoconstriction than dexfenfluramine. Am J Physiol 2003; 286: L531-L538.

32 Reeve H, Michelakis E, Nelson D, Weir E, Archer S. Alterations in a redox oxygen sensing mechanism in chronic hypoxia. J Appl Physiol 2001; 90: 2249-2256.

33 Bonnet S, Michelakis E, Porter C, et al. An abnormal mitochondrial -HIF1a - Kv channel pathway disrupts oxygen-sensing and triggers pulmonary arterial hypertension (PAH) in fawn-hooded rats: similarities to human PAH. Circulation 2006; 113: 2630-2641.

34 Yuan J, Aldinger B, Juhaszova M, et al. Dysfunctional voltage-gated $\mathrm{K}^{+}$channels in pulmonary artery smooth muscle cells of patients with primary pulmonary hypertension. Circulation 1998; 98: 1400-1406. 
35 Krick S, Platoshyn O, Sweeney M, Kim H, Yuan J. Activation of $\mathrm{K}^{+}$channels induces apoptosis in vascular smooth muscle cells. Am J Physiol Cell Physiol 2001; 280: C970-C979.

36 Rezaie-Majd S, Murar J, Nelson D, et al. Increased release of serotonin from rat ileum due to dexfenfluramine. Am J Physiol 2004; 287: R1209-R1213.

37 Guignabert C, Izikki M, Tu L, et al. Transgenic mice overexpressing the 5-hydroxytryptamine transporter gene in smooth muscle develop pulmonary hypertension. Circ Res 2006; 98: 1323-1330.
38 Cogolludo A, Moreno L, Lodi F, et al. Serotonin inhibits voltage-gated $\mathrm{K}+$ currents in pulmonary artery smooth muscle cells: role of 5-HT2A receptors, caveolin-1 and Kv1.5 channel internalization. Circ Res 2006; 98: 931-938.

39 Fantozzi I, Platoshyn O, Wong A, et al. Bone morphogenetic protein-2 upregulates expression and function of voltage-gated $\mathrm{K}+$ channels in human pulmonary artery smooth muscle cells. Am J Physiol 2006; 291: L993-L1004. 